Tropical Journal of Pharmaceutical Research December 2016; 15 (12): 2595-2602

ISSN: $1596-5996$ (print); 1596-9827 (electronic)

(c) Pharmacotherapy Group, Faculty of Pharmacy, University of Benin, Benin City, 300001 Nigeria.

All rights reserved.

Available online at http://www.tjpr.org

Original Research Article

http://dx.doi.org/10.4314/tjpr.v15i12.9

\title{
Ehrlich ascites tumor-bearing mice treated with aqueous ethanol plant extract from Euphorbia tirucalli showed signs of systemic toxicity
}

\begin{abstract}
Maicon $\mathbf{R}$ Kviecinski ${ }^{1,2 *}$, Júlia $\mathbf{R}$ dos Santos $^{2}$, Bruna $\mathbf{G}$ Magagnin ${ }^{2}$, Marina $\mathbf{R}$ Correa $^{2}$, Morgana M Clarinda ${ }^{2}$, Luciana A Trabold ${ }^{1}$, Isabela MB David ${ }^{1}$, Flávia S Fernandes ${ }^{1}$, Jane da Silva ${ }^{3}$, Luiz A Kanis ${ }^{1,2}$, Eduardo B Parisotto ${ }^{4}$, Luiza SEW Castro ${ }^{4}$, Fabiana $O$ da Silva ${ }^{4}$ and Rozangela C Pedrosa ${ }^{4}$

${ }^{1}$ Postgraduate Program in Health Sciences, Universidade do Sul de Santa Catarina, Palhoça, SC, ${ }^{2}$ Pharmacy School, Universidade do Sul de Santa Catarina, Tubarão, SC, ${ }^{3}$ Allergy Service, University Hospital Professor Polydoro de São Thiago, Universidade Federal de Santa Catarina, Florianopolis, SC, ${ }^{4}$ Department of Biochemistry, Universidade Federal de Santa Catarina, Florianópolis, Brazil
\end{abstract}

*For correspondence: Email: maicon.kviecinski@gmail.com; Tel: +55 4832791167

Received: 17 September 2016

Revised accepted: 22 November 2016

\begin{abstract}
Purpose: To evaluate the antitumor effect of a latex extract from Euphorbia tirucalli Linn. (Euphorbiaceae) and its toxicity.

Methods: Aqueous ethanol and petroleum ether extracts were obtained through maceration. Maximum tolerated dose was determined in healthy mice. Antitumor activity was measured in Ehrlich ascites tumor-bearing mice treated with the extract through intraperitoneal injection $(62.5,125$ or $250 \mathrm{mg} / \mathrm{kg})$ every $48 \mathrm{~h}$ (four doses). Efficacy was assessed by weight gain, abdominal circumference, volume of ascitic fluid and packed tumor cells, tumor cell viability and survival. Toxicity indicators were serum glucose, triglycerides, total proteins, activity of alanine and aspartate aminotransferases and mass of heart, spleen, kidney and liver. A hemolysis assay was also performed.

Results: Doses of 62.5 and $125 \mathrm{mg} / \mathrm{kg}$ caused no antitumor activity, while $250 \mathrm{mg} / \mathrm{kg}$ dose reduced weight gain (3-fold), abdominal circumference and volume of ascitic fluid (>50\%) and packed cells (50 $\%)$, but lowered tumor cell viability (40\%). However, mice treated with the extract survived for a shorter time than control mice. Furthermore, the $250 \mathrm{mg} / \mathrm{kg}$ dose caused cardiac atrophy, splenomegaly and fasting hyperglycemia. The extract caused hemolysis, and the half-maximal effective concentration $\left(E C_{50}\right)$ was $1.6(0.9-2.7) \mathrm{mg} / \mathrm{mL}$.

Conclusion: Euphorbia tirucalli extract inhibits Ehrlich ascites tumor in mice, but the therapeutic dose is also harmful to non-tumor tissues.
\end{abstract}

Keywords: Euphorbia tirucalli, Ehrlich ascites tumor-bearing mice, Antitumor, Toxicity, Cardiac atrophy, Splenomegaly

Tropical Journal of Pharmaceutical Research is indexed by Science Citation Index (SciSearch), Scopus, International Pharmaceutical Abstract, Chemical Abstracts, Embase, Index Copernicus, EBSCO, African Index Medicus, JournalSeek, Journal Citation Reports/Science Edition, Directory of Open Access Journals (DOAJ), African Journal Online, Bioline International, Open-J-Gate and Pharmacy Abstracts

\section{INTRODUCTION}

Some ethnobotanical articles reported that people from different communities and rural workers in Brazil have used the latex of
Euphorbia tirucalli Linn. (Euphorbiaceae) for the traditional treatment of cancer. In most cases, the recommendation is to dilute some drops of latex into water and take it orally [1-3]. In Brazil, Euphorbia tirucalli (E. tirucalli) is known as 
"aveloz". This plant is originally from Africa and is found in many tropical regions, grown as an evergreen plant containing latex in the aerial parts [-1-4]. There are also some claims that the latex is used on external warts [3].

Some investigations evaluating the antitumor activity of E. tirucalli support its potential for the treatment of cancer. However, literature is still lacking in vivo data and safety data. One study has shown that euphol, a triterpene from $E$. tirucalli inhibited the growth of gastric cancer cells by ERK 1/2-mediated apoptosis [5]. In vivo, one preliminary report postulated that Ehrlich tumor-bearing mice had myelosuppression and increased numbers of spleen granulocytemacrophage colony forming units. The treatment of these animals with $E$. tirucalli aqueous ethanolic extract $(125,250$ or $500 \mathrm{mg} / \mathrm{kg}$ ) through gavage daily for five days stimulated marrow myelopoiesis and reduced spleen colony formation [6].

Other studies showed that E. tirucalli is toxic [4,711]. It contains 4-deoxyphorbol ester, which can suppress the immune system and promote tumor growth. The endemicity of Burkitt's lymphoma coincides with profusion of $E$. tirucalli in tropical Africa [4]. The latex is extremely irritating to the skin and mucosa [8]. The oral administration of one drop of latex for 18 weeks caused splenomegaly in healthy mice [9]. A recent study demonstrated that eutirucallin, a lectin from the latex presents proinflammatory properties [10]. The aqueous extract from $E$. tirucalli caused cytotoxicity, genotoxicity and changes in antioxidant gene expression in human leukocytes [11].

With this background, it is evident that the internal administration of products from $E$. tirucalli must be evaluated deeper. Even when it is considered an antitumor activity, when toxicity can be used with therapeutic purposes, this cannot be useful if it is not controllable and directed preferably against tumor cells. The aim of the current study was to enhance the understanding of the antitumor activity and toxicity of E. tirucalli.

\section{EXPERIMENTAL}

\section{Plant material}

The aerial parts of E. tirucalli were collected between June and July 2013 in the western region of Santa Catarina, Brazil, and authenticated by Professor Jasper J Zanco, from
Universidade do Sul de Santa Catarina (Unisul). A voucher specimen (no. R-SRS50033) was deposited at Herbarium Laelia purpurata of the same University. This work complied with the rules governing biodiversity rights [12].

\section{Extraction}

The aerial parts of E. tirucalli consist of fleshy branches containing latex. Therefore, aerial parts were milled fresh and kept in shake-assisted maceration (1:2 weight/volume) for 2 days, repeated 3 times. An aqueous ethanol extract was made using water:ethanol (1:8). Another extract was made in parallel using petroleum ether. All solvents were Vetec $\AA$ ACS grade reagents. The solvents were eliminated under reduced pressure. Extraction performances were calculated in mass of dried extract $(\mathrm{g})$ and yield $(\%)$, taking into consideration the mass of the starting material [13].

\section{Animals}

The study was conducted in compliance with international $(\mathrm{NIH})$ guidelines [14] and had the approval of the ethics committee of Unisul (no. 13.027.4.03.IV). Male Balb/c mice $(20 \pm 5 \mathrm{~g})$ were housed under controlled conditions in the Laboratory of Neurosciences from Unisul, having food and water ad libitum. Before experiments, mice were fasted for $6 \mathrm{~h}$. Animals were allowed to acclimatize (12 h light-dark cycle, $22 \pm 2^{\circ} \mathrm{C}, 60$ $\%$ relative humidity) for at least 5 days before the experiments.

\section{Determination of maximal tolerated dose}

Groups of healthy mice $(n=6)$ were treated through intraperitoneal injections (i.p.) with up to four doses of extract $(50,100,250,350$ or 450 $\mathrm{mg} / \mathrm{kg}$ ) given every $48 \mathrm{~h}$ to determine the maximum tolerated dose by verifying the occurrence of death, hair erection, aggressiveness, dullness, inactivity and loss of appetite [15].

\section{Tumor induction and treatment}

Ehrlich carcinoma ( $5 \times 10^{6}$ cells) was inoculated into the abdomen of another set of animals [16]. Inoculation day was considered "day zero" when animals were weighed and the abdominal circumference was measured. Twenty-four hours later, animals were divided into 4 groups $(n=$ 12/each), including a control group treated (i.p.) with saline $(50 \mu \mathrm{L})$ and 3 test-groups which received aqueous ethanol extract (i.p.) at 62.5, 125 or $250 \mathrm{mg} / \mathrm{kg}$. Four doses were administered in total. Each dose was given every $48 \mathrm{~h}$. 


\section{Evaluation of antitumor activity}

On day 10, mice were weighed and the abdominal circumferences were measured one more time. Half of each group was euthanized $(n=6)$, and the ascitic fluid was collected in graduated FalconTM conical tubes. Tubes were

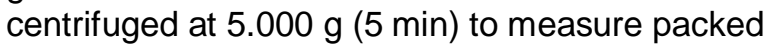
tumor cells volume [16]. Viability of tumor cells was assessed through the trypan blue assay [17]. Cells were counted by a TC10 counter (BioRad, USA). Inhibition of tumor growth (ITG) was calculated with basis on abdominal circumference change (AC) using Equation 1 [18]:

ITG $(\%)=[$ AC (test-group) $\times 100 / A C($ control $)]-10$ (1)

\section{Evaluation of mice survival}

The remaining animals of each group $(n=6)$ were monitored on a daily basis to evaluate survival using Kaplan-Meier method [19].

\section{Determination of toxicity}

The mass of heart, spleen, kidneys and liver from mice treated with the antitumor effective dose of extract $(250 \mathrm{mg} / \mathrm{kg})$ and mice from the control group $(n=6)$ was measured in a Shimadzu AUY 200 analytical balance (Japan) [15]. Blood samples were collected for estimating serum glucose, triglycerides, total proteins and activity of aspartate and alanine - aminotransferases (AST and ALT) using kits Labtest ${ }^{\circledR}$ (Brazil).

\section{Hemolysis assay}

Hemolytic test was performed in triplicate using 96-well plates [20]. Each well received saline $\left(100 \mu \mathrm{L} 0.85 \% \mathrm{NaCl}\right.$ and $\left.10 \mathrm{mM} \mathrm{CaCl}_{2}\right)$. Then, $100 \mu \mathrm{L}$ of saline containing extract $(0.08-2.5$ $\mathrm{mg} / \mathrm{mL}$ ) were added. The negative control (hemolysis $0 \%$ ) contained only saline. Triton X$100(20 \mu \mathrm{L})$ was added as positive control (100 $\%$ hemolysis). Each well received a $2 \%$ suspension of mouse erythrocytes. After incubation at room temperature (30 min) and centrifugation $(5.000 \mathrm{~g}$ for $5 \mathrm{~min}$ ), hemoglobin was quantified at $540 \mathrm{~nm}$. The half maximal effective concentration $\left(E_{50}\right)$ and $95 \%$ confidence intervals were calculated using Graph Pad Prism (San Diego, USA).

\section{Statistical analysis}

Data are presented as mean \pm standard deviation or confidence intervals. Statistical analysis was carried out using Graph Pad Prism software, analysis of variance (ANOVA) and Bonferroni test. $P<0.05$ was taken as statistically significant.

\section{RESULTS}

The yield of aqueous ethanol and petroleum ether extractions was $0.86 \pm 0.05$ and $0.14 \pm$ 0.02 , respectively. Thus, the extraction yield using water-ethanol was much higher (6-fold) than the petroleum ether extraction. Therefore, the aqueous ethanol extract was selected for screening for antitumor activity and toxicity.

Figure 1 shows the mortality of healthy mice following a first, second, third and fourth administration of extract. The maximum tolerated dose was $250 \mathrm{mg} / \mathrm{kg}$, which caused neither mortality nor behavior changes.

Considering the treatments of Ehrlich ascites tumor-bearing mice, Figure 2 (A) shows that the weight gain in mice from the saline-treated control group was $12.8 \pm 3 \mathrm{~g}$, which is a weight gain of more than $50 \%$ in comparison to the initial measurement.

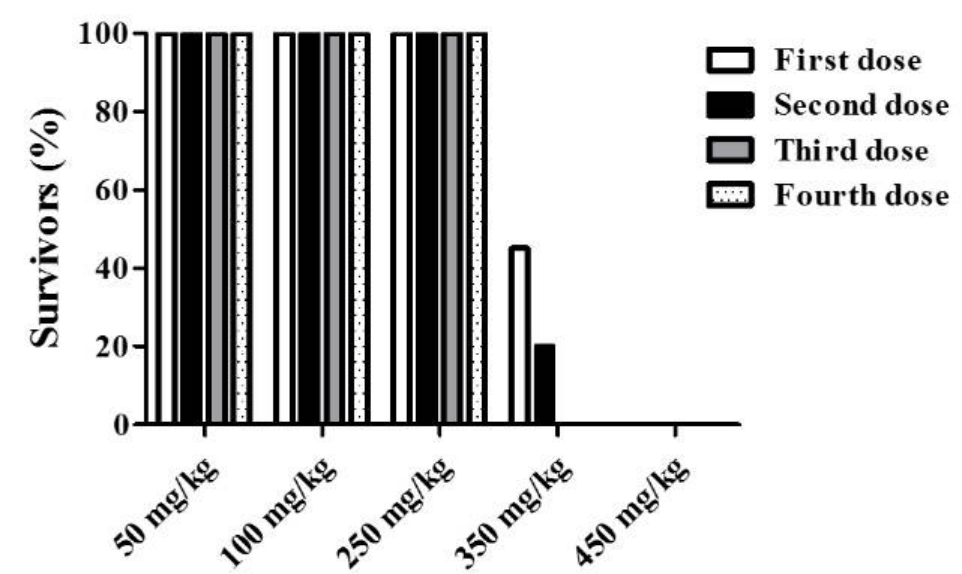

Figure 1: Mortality of healthy mice receiving doses of Euphorbia tirucalli aqueous ethanol extract every $48 \mathrm{~h}$ through intraperitoneal injections ( $\mathrm{n}=6 /$ each group) 
A.

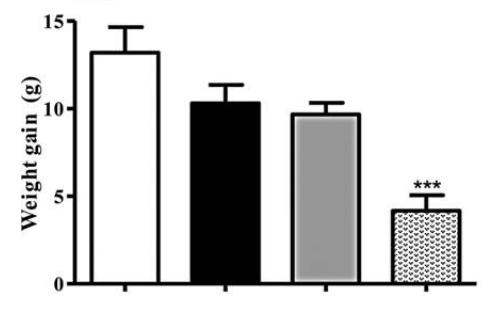

C.

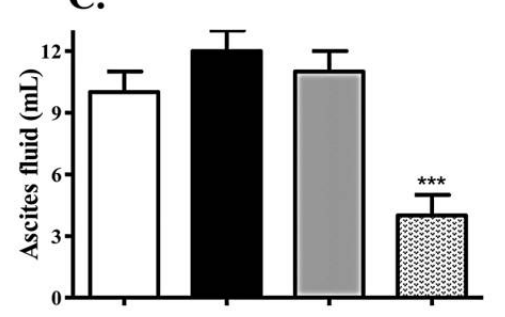

B.

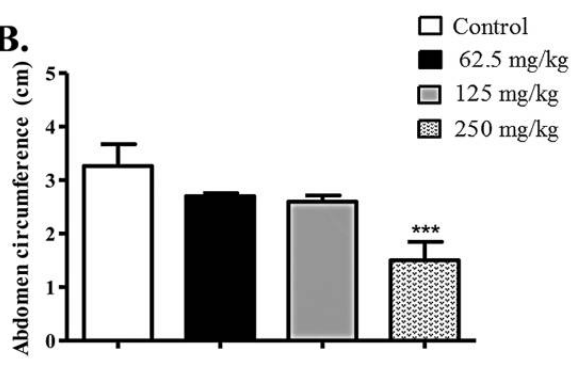

D.

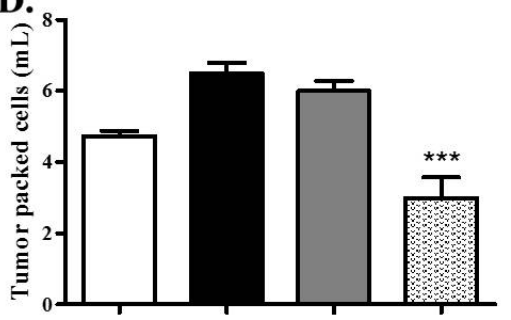

Figure 2: Weight gain (A), abdomen circumference (B), volume of ascitic fluid (C) and packed tumor cells (D) in Ehrlich ascites tumor-bearing mice treated with Euphorbia tirucalli aqueous ethanol extract $(62.5,125$ or 250 $\mathrm{mg} / \mathrm{kg})$ and the saline-treated control. Data are as means $\pm S D(n=12$ in $A$ and $B$, whereas $n=6$ in $C$ and $D)$. ${ }^{* * *}$ statistical difference compared to the control $(p<0.01)$

There were no differences in weight gain between the control and the groups dosed with extract at 62.5 and $125 \mathrm{mg} / \mathrm{kg}$. The group dosed at $250 \mathrm{mg} / \mathrm{kg}$ had a weight gain of $3.6 \pm 1.8 \mathrm{~g}$, showing a strong reduction compared to the control group.

Figure 2 also shows data of abdominal circumference $(B)$, volume of ascitic fluid $(C)$ and packed tumor cells (D). Again, no differences were observed between the control and mice treated with either 62.5 or $125 \mathrm{mg} / \mathrm{kg}$. Mice treated with $250 \mathrm{mg} / \mathrm{kg}$ showed an abdominal circumference determined at $1.5 \pm 0.6 \mathrm{~cm}$ on average, which means a reduction close to $50 \%$ compared to the control (Figure $2 \mathrm{~B}$ ). A similar trend was observed for the volume of ascitic fluid (Figure $2 \mathrm{C}$ ). The packed cells volume in mice from the control was $4.7 \pm 0.1 \mathrm{~mL}$, this value was $2.9 \pm 0.2 \mathrm{~mL}$ in mice treated with extract at 250 $\mathrm{mg} / \mathrm{kg}$.

Figure 3 (A) shows tumor cell viability. Only the treatment done with extract at $250 \mathrm{mg} / \mathrm{kg}$ reduced the number of viable tumor cells compared to the control. Therefore, if taken together the above results suggest an antitumor activity for the extract at $250 \mathrm{mg} / \mathrm{kg}$. The inhibition of tumor growth was calculated at > $40 \%$. This corroborates claims for the antitumor activity of E. tirucalli [1-3].

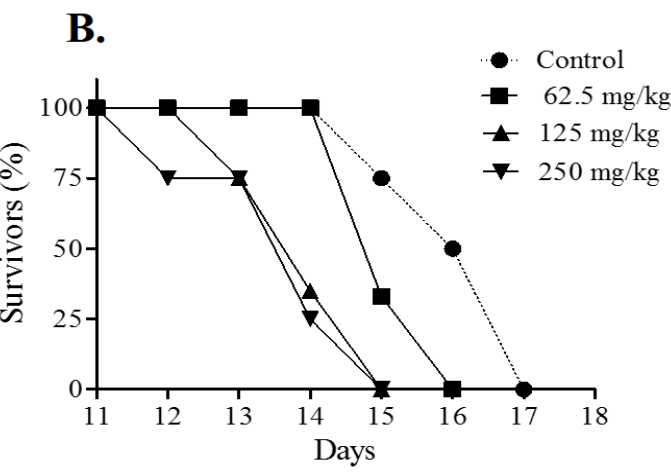

Figure 3: Number of viable tumor cells in mice treated with Euphorbia tirucalli aqueous ethanol extract. Data are means \pm SD ( $n=6 /$ each group). ${ }^{* *}$ statistical difference compared to the control $(p<0.01)(A)$. Lifespan of Ehrlich tumor-bearing mice treated with the extract at $62.5,125$ or $250 \mathrm{mg} / \mathrm{kg}$ and the saline-treated control ( $\mathrm{n}=6 / \mathrm{each}$ group) (B) 
Figure 3 (B) shows the percentage of survivors after treatments. Increase in the area under the curves indicated an increase of survival. The smallest areas corresponded to mice treated with the extract at 125 and $250 \mathrm{mg} / \mathrm{kg}$. The area was slightly larger when mice were dosed at 62.5 $\mathrm{mg} / \mathrm{kg}$. However, all mice treated with extract survived a shorter time than mice from the control.

Figure 4 shows the mass of organs of mice treated with extract at $250 \mathrm{mg} / \mathrm{kg}$ and the control. Figures $4(\mathrm{~A})$ and $4(\mathrm{~B})$ show that the mass of kidneys and liver were not affected. Figures 4 (C) and 4 (D) show evidences of cardiac atrophy and splenomegaly in mice receiving the extract.

Some serum parameters were measured to evaluate the toxicity of extract given at 250 $\mathrm{mg} / \mathrm{kg}$ (Figure 5). No differences were verified neither in terms of triglycerides (5 A), total proteins (5 B) nor activity of AST and ALT (5 $\mathrm{C} / \mathrm{D})$. However, mice treated with extract had fasting hyperglycemia compared to the control (Figure $5 \mathrm{E}$ ).
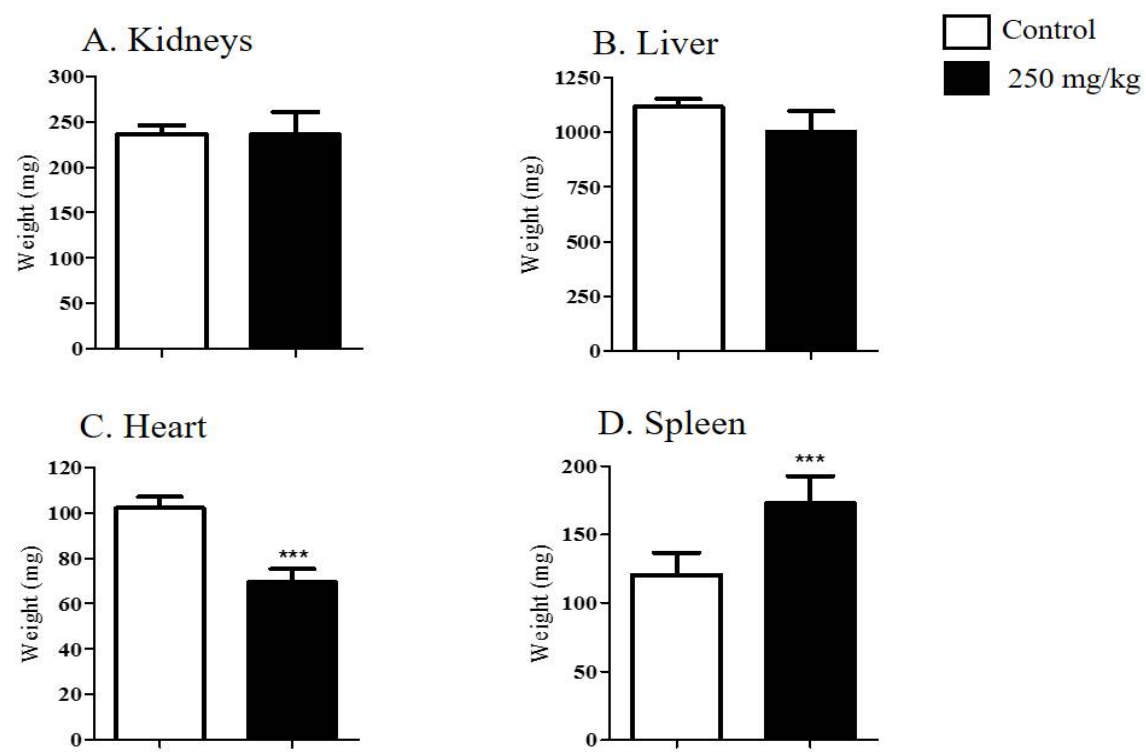

Figure 4: Mass of organs of Ehrlich tumor-bearing mice treated with Euphorbia tirucalli aqueous ethanol extract at $250 \mathrm{mg} / \mathrm{kg}$ (intraperitoneally) (closed bars). Saline-treated control group (opened bars). Data are means \pm SD $\left(\mathrm{n}=6 /\right.$ each group). ${ }^{* \star *}$ statistical difference compared to the control $(p<0.01)$
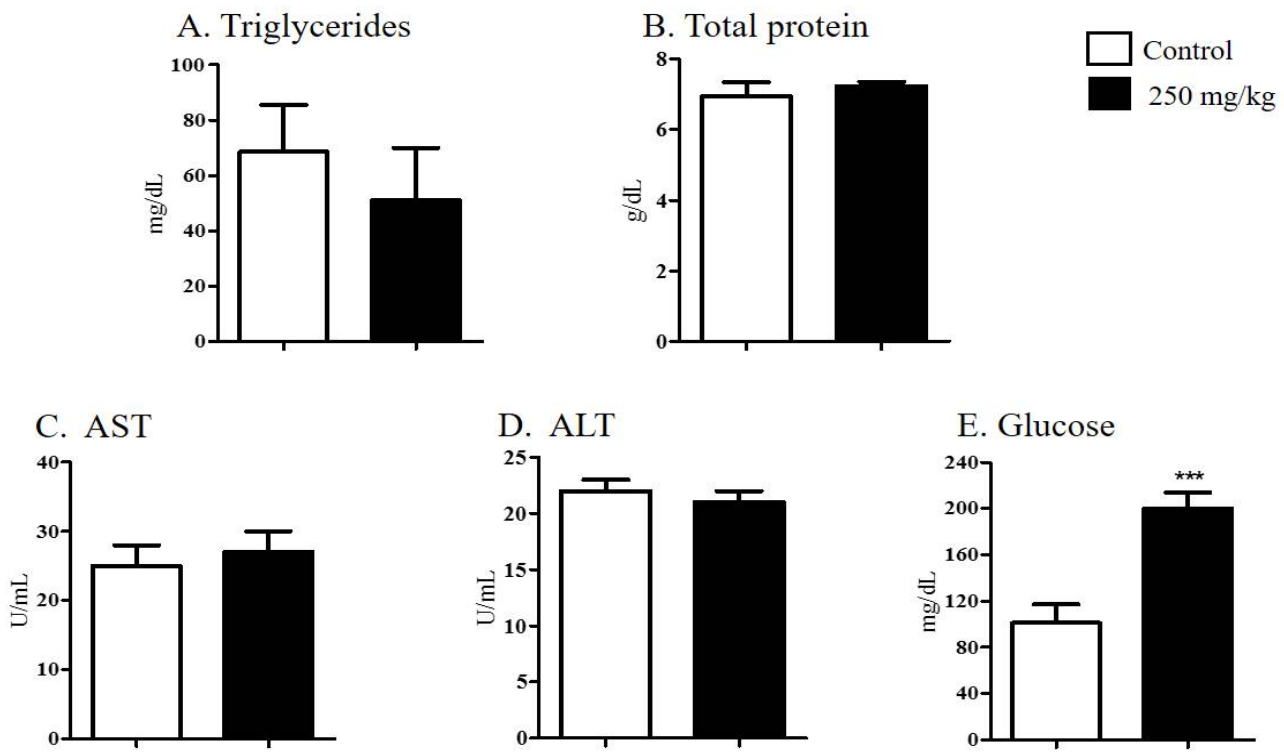

Figure 5: Serum triglycerides (A), total proteins (B), activities of aspartate AST (C) and alanineaminotransferases ALT (D) and glycemia (E) in Ehrlich tumor-bearing mice treated with Euphorbia tirucalli aqueous ethanol extract $(250 \mathrm{mg} / \mathrm{kg}$, intraperitoneally) (closed bars). Saline-treated control (opened bars). Data are means $\pm \mathrm{SD}\left(\mathrm{n}=6 /\right.$ each group). ${ }^{* * *}$ statistical difference $(p<0.01)$ 
Figure 6 shows that E. tirucalli aqueous ethanol extract caused concentration-dependent hemolysis. The $\mathrm{EC}_{50}$ value was $1.6(0.9-2.7)$ $\mathrm{mg} / \mathrm{mL}$.

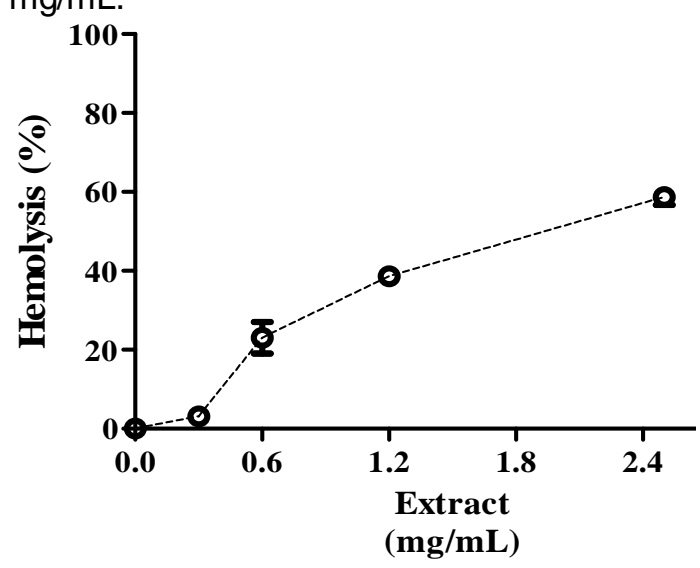

Figure 6: Hemolysis caused by Euphorbia tirucalli aqueous ethanol extract. Data of three independent experiments performed in triplicates

\section{DISCUSSION}

Some ethnobotanical studies and data of in vitro experiments suggest usefulness of $E$. tirucalli for cancer treatment $[1-3,6]$. The plant latex is toxic $[4,8-11]$. To be worthy therapeutically, this toxicity had to be evaluated when considering internal administration.

The overall data of the first phase of this investigation suggested an antitumor action of $E$. tirucalli extract administered at $250 \mathrm{mg} / \mathrm{kg}$, capable to kill tumor cells (Figure 3A). That caused reduction of volumes of ascitic fluid and packed tumor cells (Figure 2). The ascitic fluid volume gives information of requisition and nutritional status of tumor and availability of nutrients, whereas the packed tumor cells volume represents the tumor size itself [21].

This investigation started by evaluating healthy mice to determine the maximum tolerated dose of extract administered intraperitoneally (250 $\mathrm{mg} / \mathrm{kg}$ ) (Figure 1). Initially, $250 \mathrm{mg} / \mathrm{kg}$ was considered safe because healthy mice did not die and had no behavioral changes. Figure 1 shows that doses above $250 \mathrm{mg} / \mathrm{kg}$ induced toxicity (> $50 \%$ of death after a single dose at $350 \mathrm{mg} / \mathrm{kg}$ within $24 \mathrm{~h}$ ). Therefore, a range of doses (62.5 to $250 \mathrm{mg} / \mathrm{kg}$ ) was tested for antitumor activity.

Lower doses $(62.5$ and $125 \mathrm{mg} / \mathrm{kg})$ were ineffective. Only $250 \mathrm{mg} / \mathrm{kg}$ caused tumor growth inhibition. Nevertheless, data showed that the effect was poorly selective and compromised other organs. All tumor-bearing mice treated with the extract survived a shorter time than mice from the control. Dose of $250 \mathrm{mg} / \mathrm{kg}$ was safe in healthy animals (Figure 1), but this was the threshold of safety because it weakened tumorbearing mice. These mice had cardiac atrophy, splenomegaly (Figure $4 \mathrm{C} / \mathrm{D}$ ) and fasting hyperglycemia (Figure 5E).

Some drugs used for cancer are tricky because they can cause cardiotoxicity [22]. A cardiac atrophy normally represents a secondary consequence resulting from a larger systemic phenomena on [23]. It is possible that in this case it was induced by the extract.

Splenomegaly can also indicate a limitation for the treatment. In principle, the enlargement of the spleen can be associated with a variety of etiologies (infectious, neoplastic or congestive). When these causes are ruled out, splenomegaly is normally a response to hyperfunction in any disorder that usually involves abnormal erythrocytes being destroyed in the spleen [24]. The interpretation of data suggesting splenomegaly in the current study had to consider that the experiment was done in tumor bearing mice. Data suggested that tumor-bearing mice treated with the extract from $E$. tirucalli at $250 \mathrm{mg} / \mathrm{kg}$ had enlarged spleens compared to the control group (Figure 4D). Previously, Varrichio et al [9] reported that healthy mice treated with latex from $E$. tirucalli had splenomegaly.

Irrespective of whether splenomegaly was associated with the toxicity of extract, it was also verified if the extract was able to cause hemolysis. Compounds possessing biological activity may not be useful if they cause hemolysis. The hemolytic assay may reveal some information about the toxicity mechanism [25]. Data showed that E. tirucalli extract caused hemolysis (Figure 6).

The final evidence showing that the effective dose of the extract was poorly selective was because treated mice had fasting hyperglycemia (Figure 5E). In toxicology, fasting hyperglycemia is used as a marker to screen compounds with toxic effects on pancreatic beta cells [26].

\section{CONCLUSION}

E. tirucalli aqueous ethanol extract administered intraperitoneally inhibits the growth of Ehrlich ascites tumor in mice, but only at doses that are also harmful to non-tumor tissues. Further studies may be required to explore how the extract is developed to therapeutic doses without toxic effects on normal cells. 


\section{DECLARATIONS}

\section{Acknowledgement}

RC Pedrosa is a recipient of grants from Conselho Nacional de Desenvolvimento Científico e Tecnológico, Brazil (Proc. 300353/2012-0).

\section{Conflict of Interest}

No conflict of interest associated with this work.

\section{Contribution of Authors}

The authors declare that this work was done by the authors named in this article and all liabilities pertaining to claims relating to the content of this article will be borne by them.

\section{Open Access}

This is an Open Access article that uses a funding model which does not charge readers or their institutions for access and distributed under the terms of the Creative Commons Attribution License (http://creativecommons.org/licenses/by 14.0) and the Budapest Open Access Initiative (http://www.budapestopenaccessinitiative.org/rea d), which permit unrestricted use, distribution, and reproduction in any medium, provided the original work is properly credited.

\section{REFERENCES}

1. de Melo JG, Santos AG, de Amorim EL, do Nascimento SC, de Albuquerque UP. Medicinal plants used as antitumor agents in Brazil: an ethnobotanical approach. Evid Based Complement Alternat Med 2011; 2011: 114.

2. Garlet $T M B$, Irgang BE. Plantas medicinais utilizadas na medicina popular por mulheres trabalhadoras rurais de Cruz Alta, Rio Grande do Sul. Rev Bras Plantas Med 2001; 4(1): 9-18.

3. Agra MF, Silva KN, Basílio IJLD, de Freitas PF, BarbosaFilho JM. Survey of medicinal plants used in the region Northeast of Brazil. Rev Bras Farmacogn 2008; 18(3): 472-508.

4. Imai S, Sugiura M, Mizuno F, Ohigashi H, Koshimizu K, Chiba S, Osato T. African Burkitt's lymphoma: a plant, Euphorbia tirucalli, reduces Epstein-Barr virus-specific cellular immunity. Anticancer Res 1994; 14(3A): 933936.

5. Lin MW, Lin AS, Wu DC, Wang SS, Chang FR, Wu YC, Huang YB. Euphol from Euphorbia tirucalli selectively inhibits human gastric cancer cell growth through the induction of ERK1/2-mediated apoptosis. Food Chem Toxicol 2012; 50(12): 4333-4339.
6. Valadares MC, Carrucha SG, Accorsi W, Queiroz ML. Euphorbia tirucalli L. modulates myelopoiesis and enhances the resistance of tumour-bearing mice. Int Immunopharmacol 2006; 6(2): 294-299.

7. Brasileiro BG, Pizziolo VR, Raslan DS, Jamal CM, Silveira D. Antimicrobial and cytotoxic activities screening of some Brazilian medicinal plants used in Governador Valadares district. Rev Bras Cienc Farm 2006; 42(2): 195-202.

8. Furstenberger G, Hecker E. New highly irritant euphorbia factors from latex of Euphorbia tirucalli $L$. Experientia 1977; 33(8): 986-988.

9. Varrichio MCBN, Sales F, da Silva S, Kuster RM, Pyrrho AS, Castelo Branco MLT. Efeitos toxicológicos crônicos do látex bruto de E. tirucalli (Aveloz) sobre peso de fígado e baço conforme uso tradicional: Um estudo preliminar. Biofarm. 2008; 2(2): 6-11.

10. Santana SS, Gennari-Cardoso ML, Carvalho FC, RoqueBarreira MC, Santiago Ada S, Alvim FC, Pirovani CP. Eutirucallin, a RIP-2 type lectin from the latex of Euphorbia tirucalli $L$. presents proinflammatory properties. PLoS One. 2014; 9(2): e88422.

11. Waczuk EP, Kamdem JP, Abolaji AO, Meinerz DF, Bueno DC, Gonzaga TKSN, Dorow TSC, Boligon AA, Athayde ML, da Rocha JBT et al. Euphorbia tirucalli aqueous extract induces cytotoxicity, genotoxicity and changes in antioxidant gene expression in human leukocytes. Toxicol. Res. 2015; 4: 739-748.

12. Ministério do Meio Ambiente (MMA) do Brasil. Decreto Legislativo no. 2, 1992. A convenção sobre diversidade biológica (CDB) [cited 2016 oct 13]. Available from: http://www.mma.gov.br/estruturas/sbf_chm_rbbio/_arqui vos/cdlbport_72.pdf

13. Handa SS. An overview of extraction techniques for medicinal and aromatic plants. In: Handa SS, Khanuja SPS, Longo G, Rakesh DD, Eds. Extraction technologies for medicinal and aromatic plants. Trieste: International Centre for Science and High Technology; 2008; pp 21-52.

14. National Research Council (US) Committee for the Update of the Guide for the Care and Use of Laboratory Animals. Guide for the Care and Use of Laboratory Animals. 8th edition. Washington (DC): National Academies Press (US); 2011. 220 p. Available from: https://grants.nih.gov/grants/olaw/Guide-for-the-Careand-use-of-laboratory-animals.pdf

15. Mello JRB, Mello FB, Langeloh A. Pre-clinic toxicity of a phytoterapic containing Anemopaegma mirandum, Cola nítida, Passiflora alata, Paulinia cupana, Ptychopetalum olacoides and thiamin chirhydrate. Lat Am J Pharm. 2010; 29(1): 57-63.

16. Biscaro F, Parisotto EB, Zanette VC, Gunther TM, Ferreira EA, Gris EF, Correia JF, Pich CT, Mattivi F, Filho DW et al. Anticancer activity of flavonol and flavan3-ol rich extracts from Croton celtidifolius latex. Pharm Biol. 2013; 51(6): 737-743.

17. Strober W. Trypan blue exclusion test of cell viability. Curr Protoc Immunol. 2001; Appendix 3B.

Trop J Pharm Res, December 2016; 15(12): 2601 
18. Farias MS, Pich CT, Kviecinski MR, Bucker NC, Felipe $K B$, Da Silva FO, Günther TM, Correia JF, Ríos $D$, Benites $J$ et al. Substituted 3-acyl-2-phenylamino-1,4naphthoquinones intercalate into DNA and cause genotoxicity through the increased generation of reactive oxygen species culminating in cell death. $\mathrm{Mol}$ Med Rep. 2014; 10(1): 405-410.

19. Kaplan EL, Meier P. Nonparametric estimation from incomplete observations. J Am Stat Assoc. 1958; 53(282): 457-481.

20. Berlinck RG, Ogawa CA, Almeida AM, Sanchez MA, Malpezzi EL, Costa LV, Hajdu E, de Freitas JC. Chemical and pharmacological characterization of halitoxin from Amphimedon viridis (Porifera) from the southeastern Brazilian coast. Comp Biochem Physiol C Pharmacol Toxicol Endocrinol. 1996; 115(2): 155-163.

21. Prasad SB, Giri A. Antitumor effect of cisplatin against murine ascites Dalton's lymphoma. Indian J Exp Biol. 1994; 32(3): 155-162.
22. Zhang S, Liu X, Bawa-Khalfe T, Lu LS, Lyu YL, Liu LF, Yeh ET. Identification of the molecular basis of doxorubicin-induced cardiotoxicity. Nat Med. 2012; 18(11): 1639-1642.

23. Razeghi $P$, Taegtmeyer $H$. Hypertrophy and atrophy of the heart: the other side of remodeling. Ann N Y Acad Sci. 2006; 1080: 110-119

24. Matacia-Murphy GM, Sacher RA. Splenomegaly: background, etiology, epidemiology [updated 2014 Sep 5; cited 2015 Oct 5]. Medscape [Internet]. Available from: http://emedicine.medscape.com/article/206208overview

25. Zohra M, Fawzia A. Hemolytic activity of different herbal extracts used in Algeria. Int J Pharm Sci Res. 2014; 5(08): 495-500.

26. Leiter EH. Multiple low-dose streptozotocin-induced hyperglycemia and insulitis in C57BL mice: influence of inbred background, sex, and thymus. Proc Natl Acad Sci USA. 1982; 79(2): 630-634. 